\title{
VARIATION OF SOME NEW MORPHOLOGICAL CHARACTERS IN THE FIELD PEAS (PISUM SATIVUM L.)
}

\author{
Nicolaie Ionescu $^{{ }^{1 *}, \text { Cătălin Dinuță }}{ }^{1}$, Diana Popescu ${ }^{1}$, Oana Badea ${ }^{1}$, Cristina Ghiorghe ${ }^{1}$, \\ Magdalena Podea ${ }^{1}$, Mariana Nicolaie ${ }^{1}$, Robert Gheorghe ${ }^{1}$ \\ ${ }^{1}$ Agricultural Research and Development Station Pitești, \\ Piteşti-Slatina road km. 5, 117030, Pitești, România
}

\begin{abstract}
Peas, as a valuable nutritious and cultivated plant (Myers et al., 2010), have recently received special attention for the improvement of new varieties (Kreplak et al., 2019). They are increasingly adapted to any kind of environmental conditions. Thus, we want an increased production of grains, contents in active principles as high as possible (Pownall et al., 2010), but also to increase its proportion in the structure of crops on a farm. The Alvesta variety, studied for its specific morphological characters, is one of the newest creations. Even in the slightly drier conditions of the last period (two years), this variety formed plants with heights of $42-45 \mathrm{~cm}$, with a total plant weight of $7.5 \mathrm{~g} .10$ knots were formed on a pea stem (at one node the floral and fruit raceme are caught and formed). Each plant formed 4 pods, weighing $6 \mathrm{~g}$ and 16 berries weighing 4.5-6 g. The bean had a diameter of $7 \mathrm{~mm}$ and the absolute weight of the berries was $215 \mathrm{~g}$. Among these morphological characters were obtained significantly positive correlations in most cases. Insignificant situations were between the absolute mass of the berries with the size of the plant, with the number of nodes, with the total number of pods and with the number of berries on a plant. Only one insignificant negative correlation was observed between the number of nodes on the stem and the diameter of the grains. Regarding the variability of the determined characters, slightly higher values were found, mainly due to the existence of the dry bottom. And yet the Alvesta variety, with improved morphological characters proved to be a good adaptability to zonal cultivation conditions.
\end{abstract}

Keywords: grains, Pisum sativum, pods, variability.

\section{INTRODUCTION}

Pea [Pisum sativum L., pro syn. P. sativum ssp. arvense (L.) Asch., Dun (gray- brown) pea, Kapucijner pea, Austrian winter pea] proves very favorable agronomic and culinary qualities. Thus, the plant has a short period of vegetation, located in very early spring, fixes atmospheric nitrogen $\left(\mathrm{N}_{2}\right)$ (common feature of all species in the family Fabaceae), structures and enriches the soil in nitrates $\left(\mathrm{NO}_{3}{ }^{-}\right)$, directly assimilable and ensures adequate rotation of crops. Atmospheric nitrogen fixation is based on the activity of symbiotic bacteria of the Bradyrhizobium type $\left(\mathrm{N}_{2}\right.$ is converted to ammonia, by a path of type: a) $\mathrm{N}_{2}+8 \mathrm{H}^{+}+8 \mathrm{e}=2 \mathrm{NH}_{3}+\mathrm{H}_{2}$ and then in assimilable form expressed by the ammonium ion: b) $\mathrm{NH}_{3}+\mathrm{H}^{+}=\mathrm{NH}_{4}^{+}$). In nodules the bacterium produces aminoacids, with which proteins are formed. After harvesting the plants, the nodules left in the soil decompose, and the accumulated amino- acids are also converted biologically into nitrates $\left(\mathrm{NO}_{2}{ }^{-}\right)$. 
They become available for wheat plants that usually follow in crop rotation (Lawrence \& Grant, 1963). Peas are rich in fiber, protein, vitamins $\mathrm{A}, \mathrm{B} 6, \mathrm{C}$ and $\mathrm{K}$, as well as the elements $\mathrm{P}, \mathrm{Mg}, \mathrm{Cu}$, $\mathrm{Fe}, \mathrm{Zn}$ and lutein. The peptide fractions in the grains also contribute to the elimination of free radicals (glutathione) as well as to the inhibition-blocking of linoleic acid oxidation. Genetically, the karyotype consists of 7 chromosomes $(2 n=14, n=7)$ ), of which 5 are acrocentric and 2 submetacentric (Ellis \& Poyser, 2002). From a botanical point of view, field peas produce 3-9 grains in pods. The grains have a globular aspect and the colors have shades of green and yellow. The absolute mass (mass of one thousand grains - MTG) has values between 50-450 g. The biomass of the whole plant includes $35-50 \%$ grains. To study the variability of some morphological characters in the cultivated pea variety, the following were determined: height, plant weight, number of nodes per stem, number and weight of pods, number and weight of grains, grain diameter and mass of one thousand grains (MTG).

\section{MATERIALS AND METHODS}

The determinations were made during July in the last two years. Plants were chosen from experiments located in the specific field of research. The cultivation technology was the one recommended by the resort. At maturity, 100 plants were harvested by a zig-zag movement from the soil cultivated annually on approx. 0.5 ha. The cultivated variety was Alvesta, which has the following characteristics: it is a new variety, of the afila type, being semi-early, low-sized and forming yellow, large, round grains, with an absolute mass of $240 \mathrm{~g}$. The plants harvested in the field have were brought to the laboratory and dried for a few days to obtain the lowest possible humidity (equilibrium). The height and weight of the whole plant were measured, the nodes formed on the stem, the number and weight of the pods formed, the number, weight and thickness of the grains were counted, then the absolute mass of the grains in the form of a thousand grains.

The results obtained represent the average of the two years of culture/crop. The obtained morphological characters were analyzed by the method of histograms (frequency polygons). Within the method, class intervals were also used as absolute values. The study highlighted several aspects, namely: the modal/high values (MV), the limits of the intervals of variability of the studied characters and the specifics of each character of the variety in the analyzed area. Simple correlations were established between the analyzed characters, with the help of which their tendencies could be observed within the studied Alvesta variety. The testing of the values was done with the theoretical values for the transgression probabilities for $0.5 \%, 1 \%$ and $0.1 \%$. Expressing values was used with Excel. In the statistical calculation of all the determined characters, the analysis of variance (anova test) was used, namely on the variation strings.

Statistical parameters were calculated using the formulas:

$\overline{\mathrm{a}}=\Sigma \mathrm{x} / \mathrm{n}$, where $\overline{\mathrm{a}}=$ the average of the determinations, and $\mathrm{x}=$ the determined values,

$\mathrm{S}^{2}($ variance $)=1 /(\mathrm{n}-1)\left[\Sigma \mathrm{x}^{2}-(\Sigma \mathrm{x})^{2} / \mathrm{n}\right]$,

$S($ standard error $)=\sqrt{ }\left(S^{2}\right)$,

$\mathrm{S} \%($ coefficient of variation $)=\mathrm{S} / \overline{\mathrm{a}} .100$.

\section{RESULTS AND DISCUSSIONS}

Variability of some plant characters. In general, field pea varieties are characterized by relatively lower plant heights (Bâlteanu \& Bîrnaure, 1989; Sturzu et al., 2016). In absolute value, the waist can reach $50-60 \mathrm{~cm}$. However, the positioning of the stem is at first relatively vertical, while towards maturity it can bend and even lie on the ground. In the case of the present, sharpened type, 


\section{Current Trends in Natural Sciences}

Vol. 10, Issue 20, pp. 93-101, 2021

https://doi.org/10.47068/ctns.2021.v10i20.013

Current Trends in Natural Sciences (on-line)

ISSN: 2284-953X

Current Trends in Natural Sciences (CD-Rom)

ISSN: 2284-9521

ISSN-L: 2284-9521

ISSN-L: 2284-9521

the plants are attached to each other by the tendrils (modified leaves), so that their bearing remains approximately vertical in most of the vegetation. Even when the climate abounds in rainfall, at harvest, given the weight of the pods on a plant, the pea lies in varying degrees on the ground. In this case, the harvested plants had a position to bend, without touching the ground. From the determinations made, the Alvesta variety had plant lengths between 30 and $54 \mathrm{~cm}$ (figure 1).

The plants between 36 and $45 \mathrm{~cm}$ dominated, but the modal value was $42-45 \mathrm{~cm}$ (18\% each). Plants with small lengths $(30 \mathrm{~cm})$ accounted for $5 \%$, and the largest $(51-54 \mathrm{~cm})$ accounted for $2-3 \%$ of the total. The appearance of the Alvesta variety at the beginning of the vegetation shows the characteristic of "joining" the plants through the stems (figure 2).

The total weight of the plants ranged from $2.2 \mathrm{~g}$ to over $20 \mathrm{~g}$. The plants dominated with $7.5 \mathrm{~g}$ (36\%) (figure 3). High values were in the range of 5-12.5 g. Regarding the number of nodes on a plant, it was between 4 and 20. Dominated the plants with 10 nodes (26\%) (figure 4). Dominant also were the plants with 8 to 16 nodes on a plant.

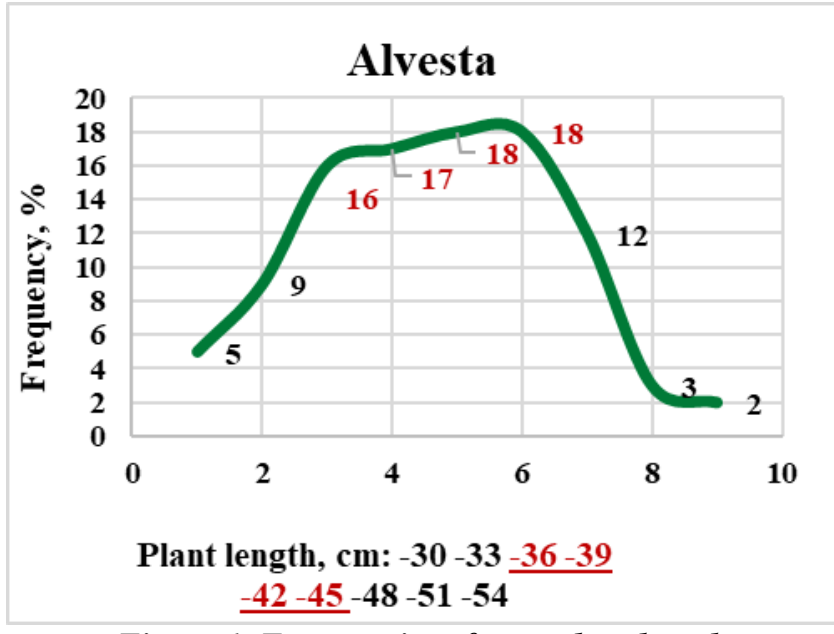

Figure 1. Frequencies of peas plant length

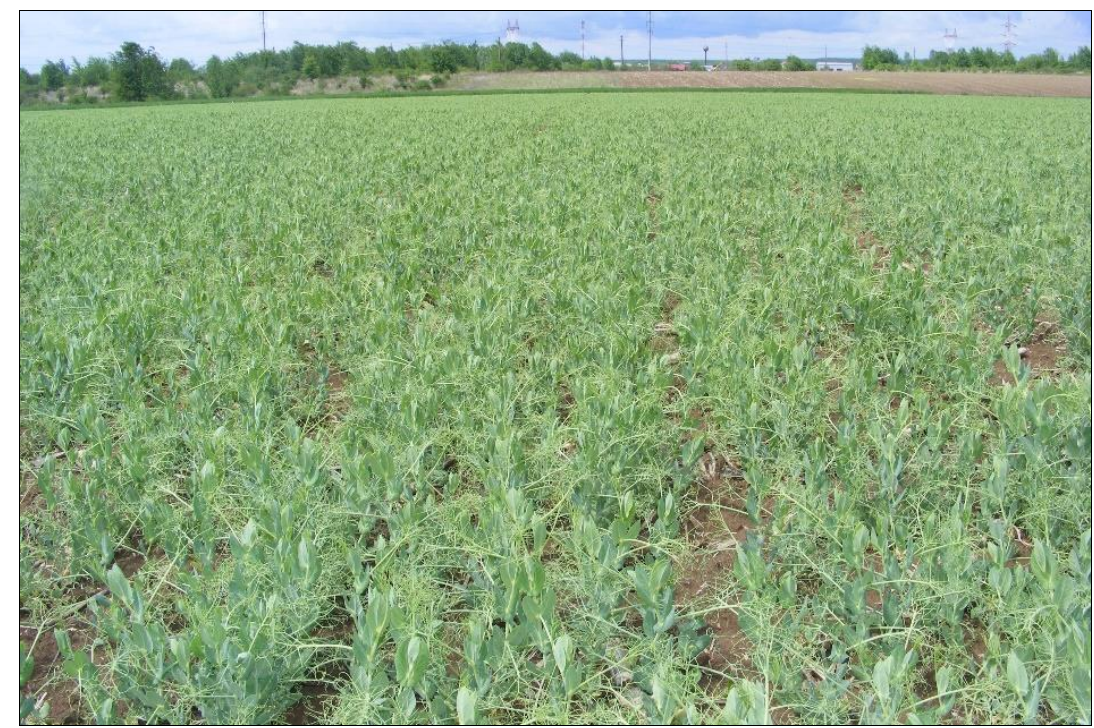

Figure 2. Alvesta variey after sprouting, march time 


\section{Current Trends in Natural Sciences}

Vol. 10, Issue 20, pp. 93-101, 2021

https://doi.org/10.47068/ctns.2021.v10i20.013

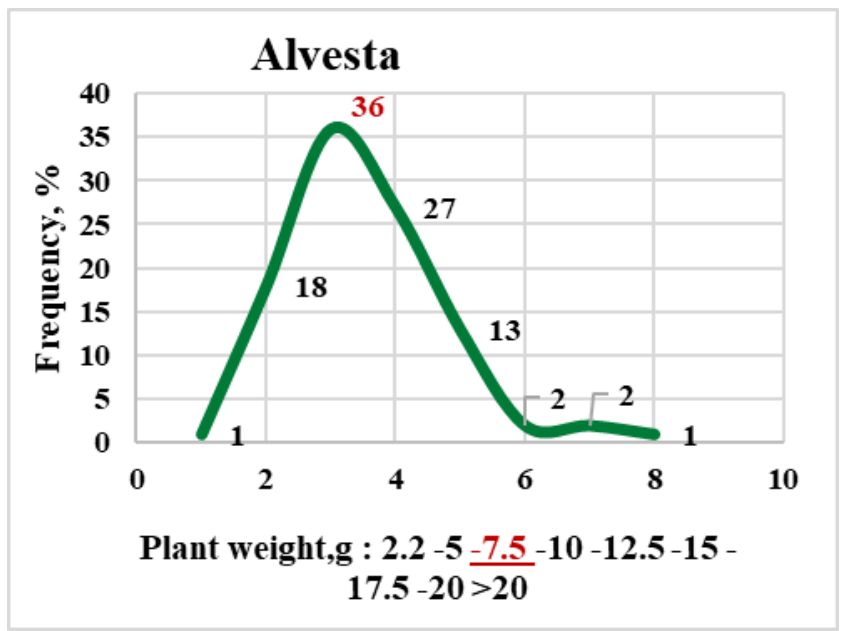

Figure 3. Frequencies of peas plants weight

Variability of pods and grains. Depending on the climatic conditions the pea plant produces a significant number of pods. In the experiment, the plants formed between 2 and over 9 pods (figure $5)$. They dominated the plants that formed 4 pods each (26\%). Close to these were plants with 5 pods $(20 \%)$ and those with 6 pods $(18 \%)$. Pea plants with $8-9$ pods accounted for only $3 \%$ of the total.

The pods formed on each plant weighed between $2 \mathrm{~g}$ and over $14 \mathrm{~g}$ (figure 6). Of these, plants with a total weight of $6 \mathrm{~g} \mathrm{(31 \% )} \mathrm{dominated.} \mathrm{Near} \mathrm{these} \mathrm{were} \mathrm{those} \mathrm{with} 4 \mathrm{~g}$ (30\% and $8 \mathrm{~g} \mathrm{(23 \% ).} \mathrm{Plants}$ with pods of 14 grams per plant have constituted only $1 \%$.

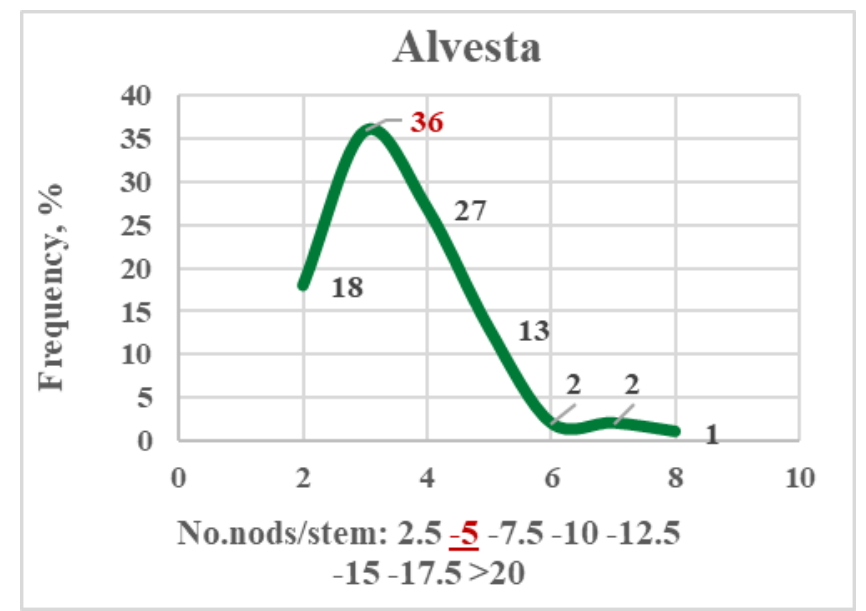

Figure 4. Frequencies of peas nods number per plant 


\section{Current Trends in Natural Sciences}

Vol. 10, Issue 20, pp. 93-101, 2021

https://doi.org/10.47068/ctns.2021.v10i20.013

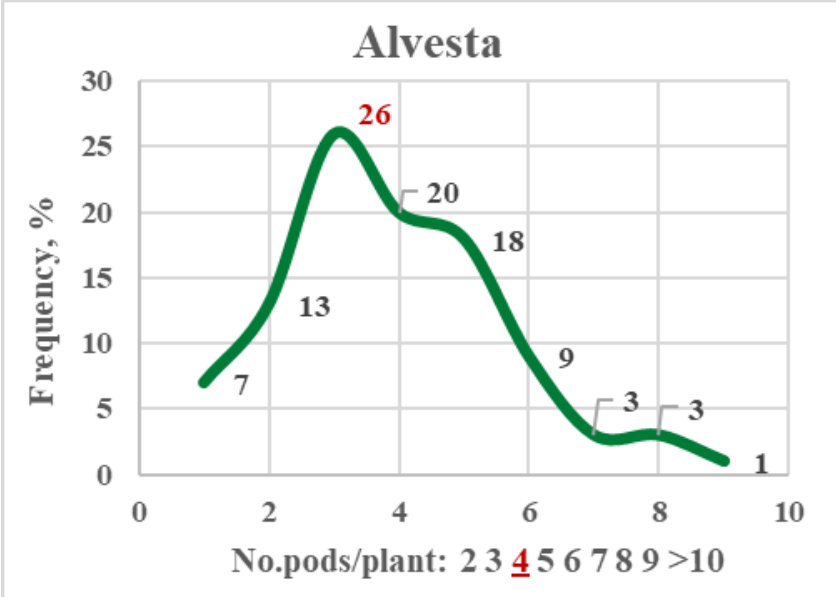

Figure 5. Frequencies of peas pods number per plant

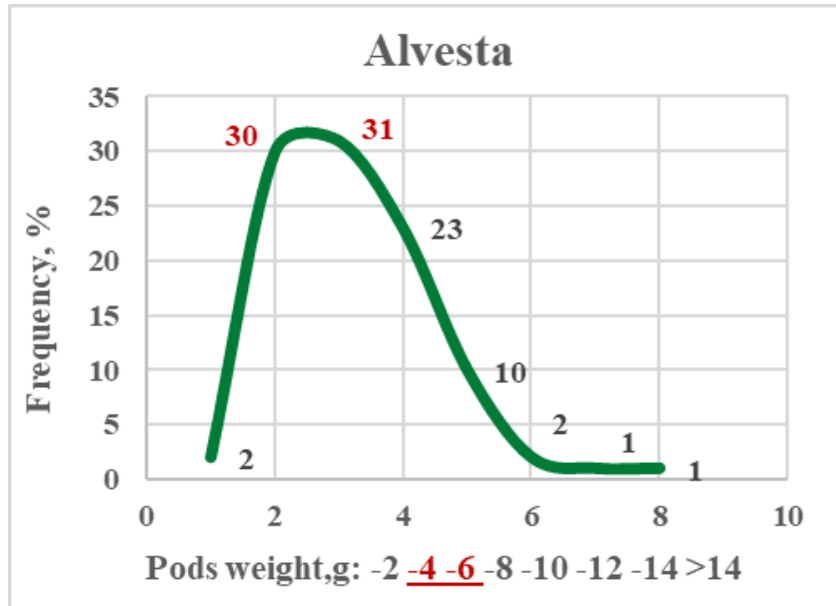

Figure 6. Frequencies of peas pods weight per plant

In these pods the plant forms number of grains, depending on the genetic capacity of the variety, climatic and cultivation conditions. In the case of the Alvesta variety, between 7 and over 36 berries were determined from one plant (figure 7). The modal value was 16 grains (18\%). Close to this were the plants with 19 berries (16\%), those with 22 berries (14\%) and those with 25 berries (10\%). Pea plants with over 36 berries / plant accounted for 3\%. The density of the plants and the appearance of the pods are shown in figure 8 (in the green stage and in figure 12 in the ripening stage). 


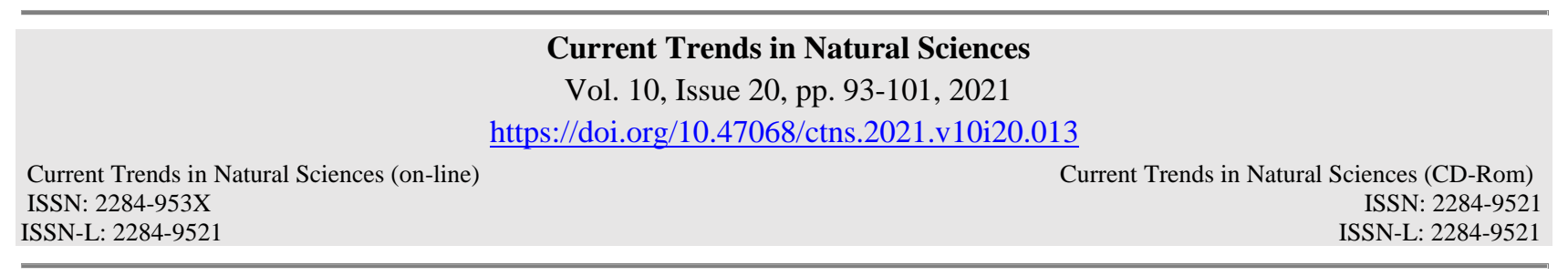

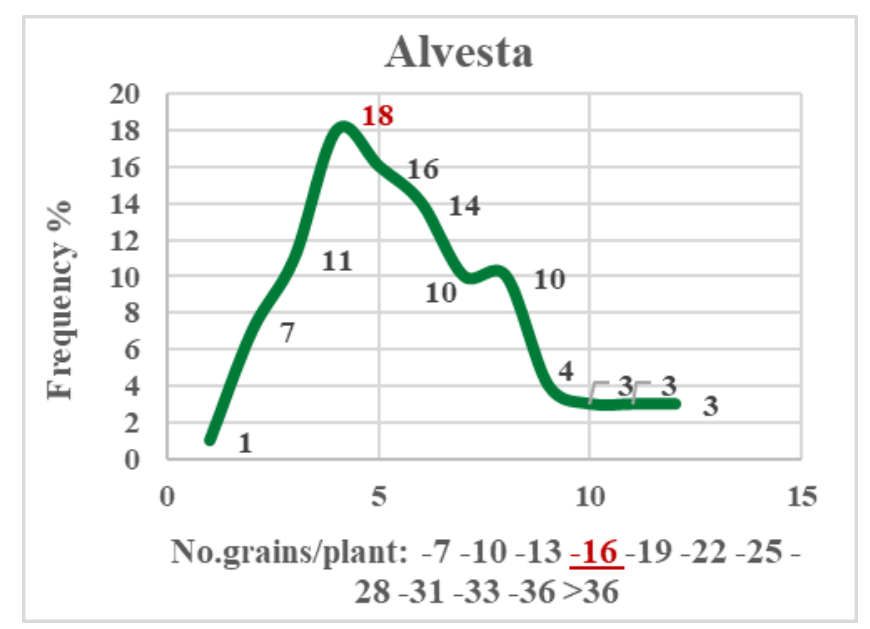

Figure 7. Frequencies of peas grains number per plant

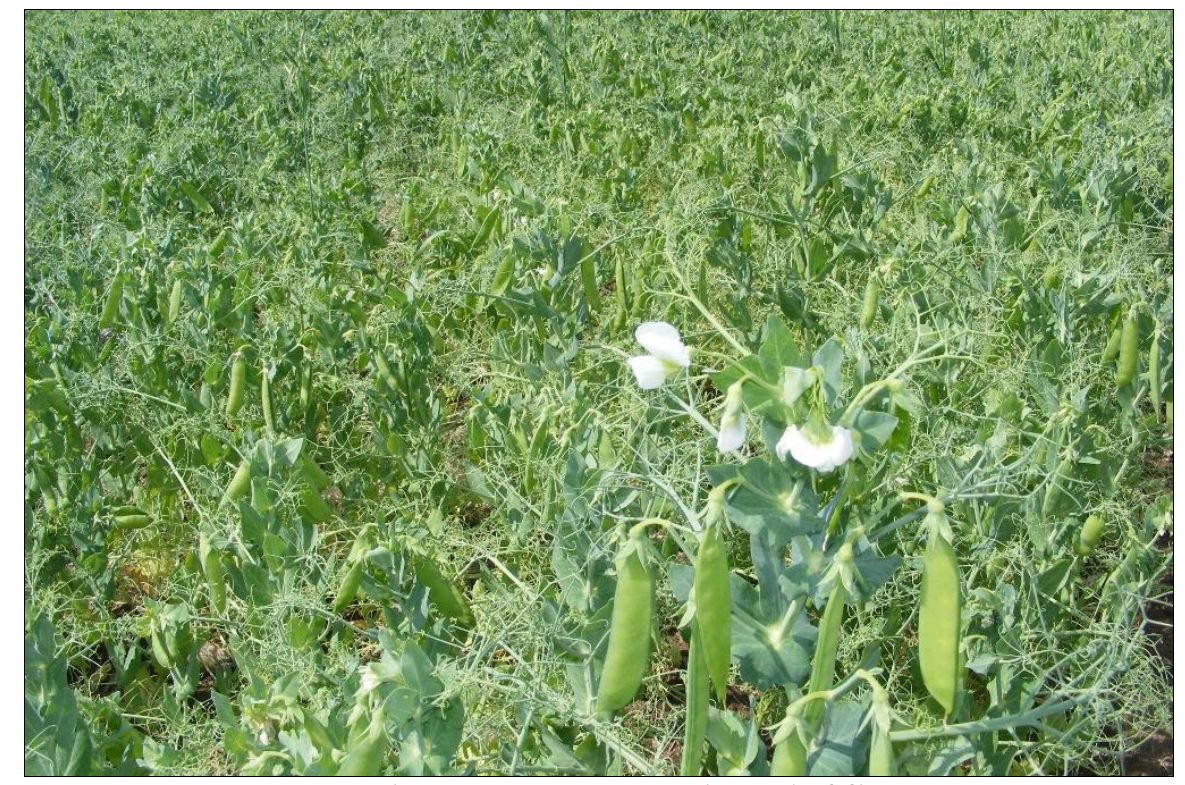

Figure 8. Alvesta peas variety at the end of flowering

The total mass of berries on a pea plant ranged from $1.5 \mathrm{~g}$ to over $10.5 \mathrm{~g}$ (Figure 9). They dominated the plants whose berries weighed 4.5-6 g (27-30\%). These were followed frequently by plants with $3 \mathrm{~g}$ grain weight (23\%). Plants with grains over $10.5 \mathrm{~g}$ constituted only $1 \%$.

The physical appearance of peas describes an approximately globular shape. In their determinations, the analysis of their diameter was used. The data resulted fairly wide range of this parameter. Thus, the limits were between $5.5 \mathrm{~mm}$ and $8.5 \mathrm{~mm}$ (figure 10). The grains with a circumference of $7 \mathrm{~mm}$ (31\%) dominated. The frequencies were $6.5 \mathrm{~mm}(27 \%)$ and $7.5 \mathrm{~mm}(23 \%)$ in diameter. The values were generally between the normal values of this crop plant.

The absolute weight of the grains (expressed in MMB values) also had fairly wide range. Thus, it was between $170 \mathrm{~g}$ and $320 \mathrm{~g}$ (Figure 11). The grains dominated with $215 \mathrm{~g}$ (20\%), followed by those with $230 \mathrm{~g}(19 \%)$ and those with $245-260 \mathrm{~g}$ (15\% each). 


\section{Current Trends in Natural Sciences}

Vol. 10, Issue 20, pp. 93-101, 2021

https://doi.org/10.47068/ctns.2021.v10i20.013

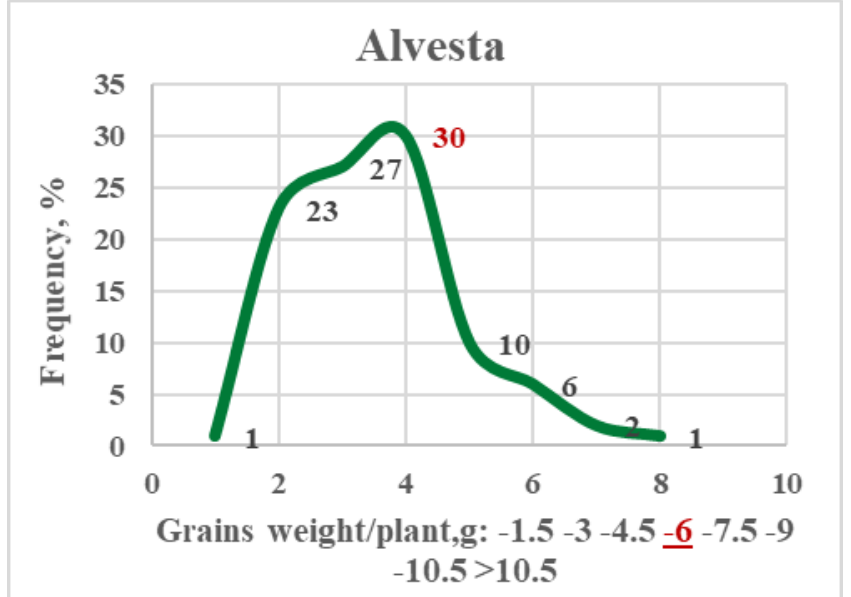

Figure 9. Frequencies of peas total grains weight

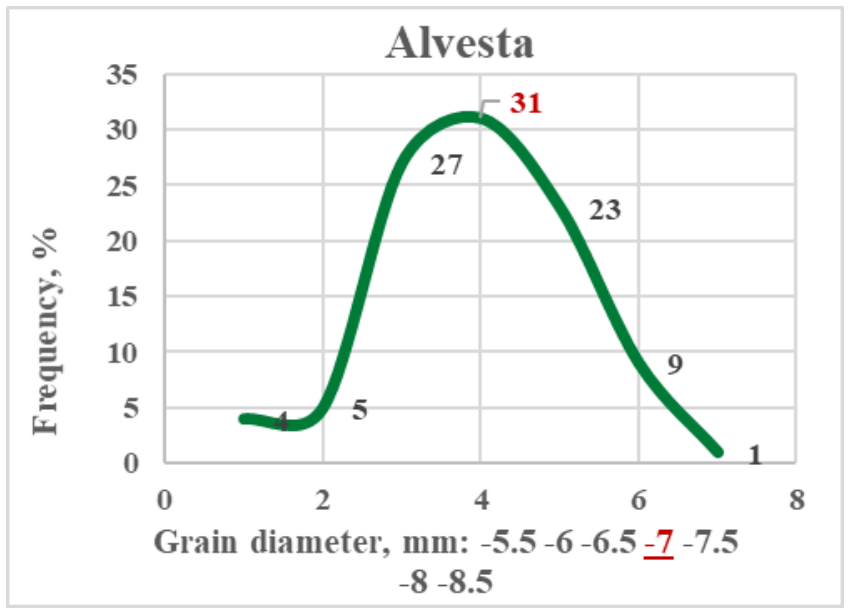

Figure 10. Frequencies of peas grains diameter

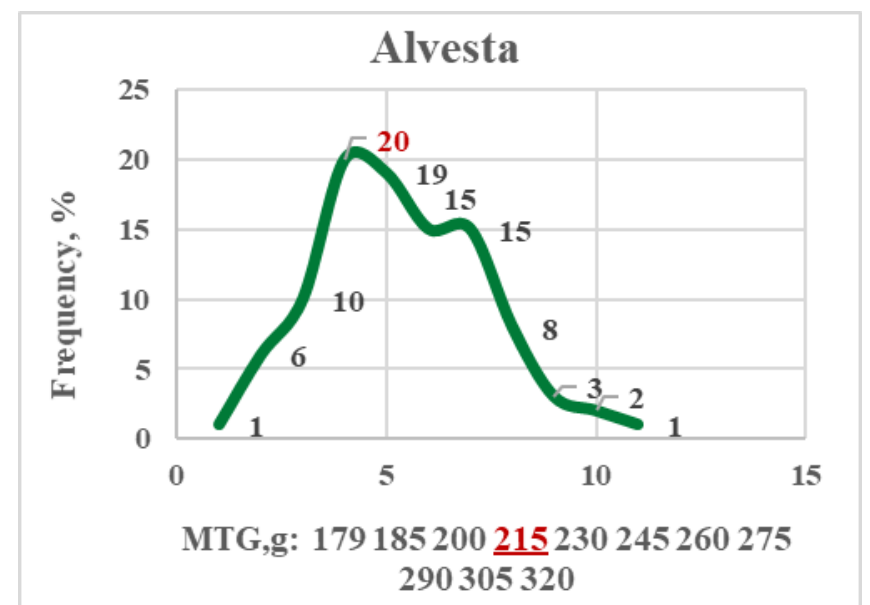

Figure 11. Frequencies of peas mass of thousand grains (MTG) 


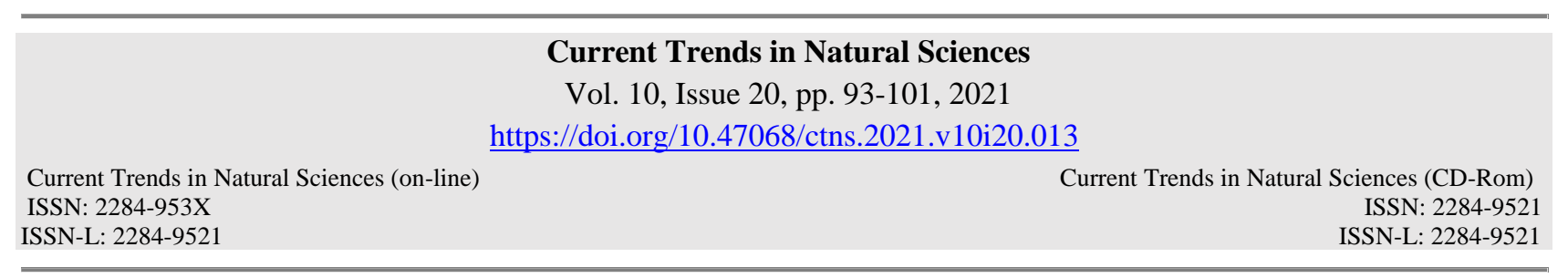

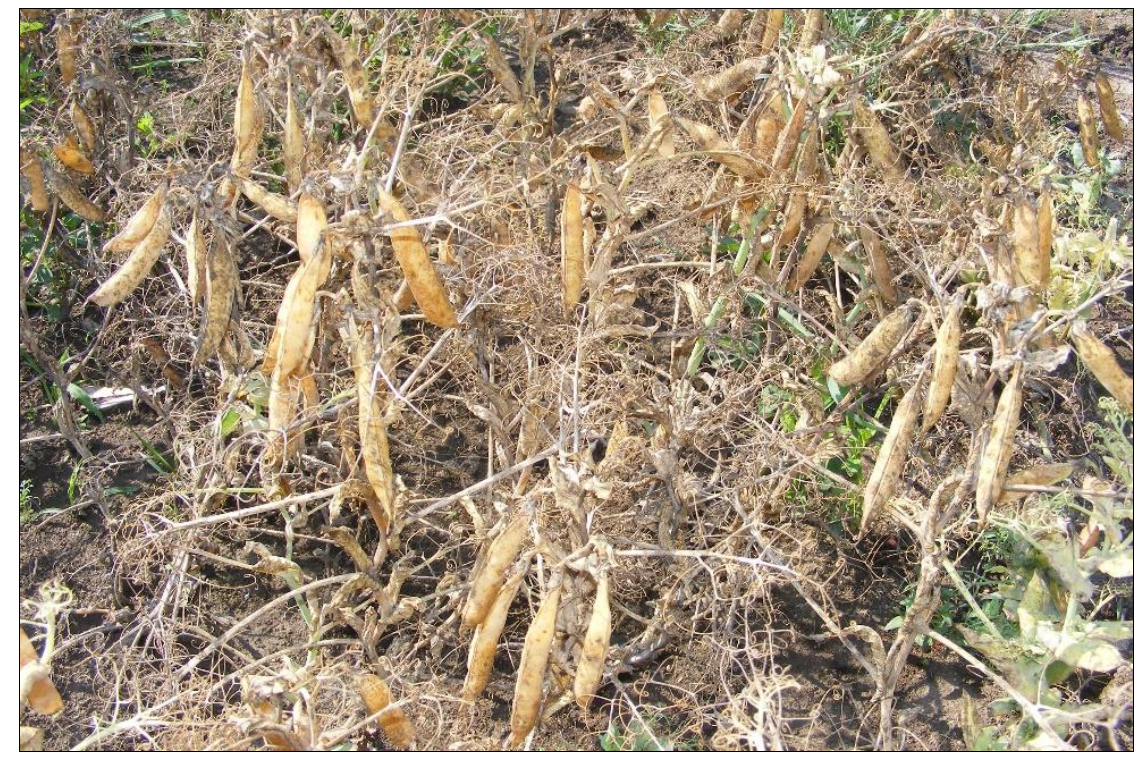

Figure 12. Peas plants at maturity period

Correlations between morphological characters. At the level of the whole set of correlations between all the characters analyzed for this pea variety, statistically assured correlations were obtained in most cases. Of these, the positive correlations between the weight of the plant and the other characters related to it were noted (correlation coefficients obtained: .356 and .975). Instead, an insignificant connection was obtained between the length of the plant and the number of nodes per stem. A negative correlation was also found between the number of nodes with the grain diameter (-.050). The mass of one thousand grains showed oscillations with the other characters analyzed (table 1).

Table 2. Correlations between the main characters of peas plant, Alvesta variety

\begin{tabular}{|c|c|c|c|c|c|c|c|c|}
\hline Indices & $\begin{array}{c}\text { Plant } \\
\text { weight, } \mathrm{g}\end{array}$ & $\begin{array}{c}\text { Nods } \\
\text { number }\end{array}$ & $\begin{array}{c}\text { Pods } \\
\text { number }\end{array}$ & $\begin{array}{c}\text { Pods } \\
\text { weight, } g\end{array}$ & $\begin{array}{c}\text { Grain } \\
\text { number }\end{array}$ & $\begin{array}{c}\text { Grain } \\
\text { weight, } g\end{array}$ & $\begin{array}{c}\text { Grain } \\
\text { diam., mm }\end{array}$ & MTG, g \\
\hline Plant length, $\mathrm{cm}$ & $.238 *$ & .079 & $.256 * *$ & $.262 * *$ & $.274 * *$ & $.277 * *$ & .019 & .111 \\
\hline Plant weight, $g$ & 1 & $.356 * * *$ & $.873 * * *$ & $.975 * * *$ & $.907 * * *$ & $.957 * * *$ & $.231 *$ & $.352 * * * *$ \\
\hline Nods number & & 1 & .183 & $.238 *$ & $.196 *$ & $.205 *$ & -.050 & .040 \\
\hline Pods number & & & 1 &. $\mathbf{8 8 2} * * *$ & $.898 * * *$ & $.879 * * *$ & .108 & .114 \\
\hline Pods weight, g & & & & 1 & $.931 * * *$ & $.982 * * *$ & $.231 *$ & $.351 * * *$ \\
\hline Grains number & & & & & 1 & .958*** & .107 & .062 \\
\hline Grains weight, $\mathrm{g}$ & & & & & & 1 & $.219 *$ & $.332 * * *$ \\
\hline Grain diameter, $\mathrm{mm}$ & & & & & & & 1 & $.477 * * *$ \\
\hline MTG, gr & & & & & & & & 1 \\
\hline
\end{tabular}

Statistical analysis of morphological characters in pea plants. The results obtained in the morphological analysis of some peas characters showed specific aspects (table 2). Thus, the length (height) of the plant measured an average of $39 \mathrm{~cm}$. This character had the average variability, namely $14 \%$. The weight of an average plant, at maturity, was $7.5 \mathrm{~g}$. The coefficient of variability was high, $42 \%$. 11 knots were formed on an average pea stem, and its expression was $31 \%$ variability. The average number of pods of 5 , the weight of the pods of $5.6 \mathrm{~g}$, the number of grains 20 and the weight of the grains of $4.6 \mathrm{~g}$, had great variability (between 37 and $43 \%$ ). The average 
pea bean had a diameter of $6.76 \mathrm{~mm}$, with low variability $(10 \%)$. The mass of one thousand grains was on average $228 \mathrm{~g}$, with an average variability of $13 \%$.

Tabel 1 Statistical indices of peas morphological characters, Alvesta variety

\begin{tabular}{|c|c|c|c|c|c|c|c|c|c|}
\hline \multirow{2}{*}{ Indices } & \multicolumn{10}{|c|}{ Caracteristicile determinate } \\
\cline { 2 - 10 } & $\begin{array}{c}\text { Plant } \\
\text { length }\end{array}$ & $\begin{array}{c}\text { Plant } \\
\text { weight }\end{array}$ & $\begin{array}{c}\text { Nods } \\
\text { number }\end{array}$ & $\begin{array}{c}\text { Pods } \\
\text { number }\end{array}$ & $\begin{array}{c}\text { Pods } \\
\text { weight }\end{array}$ & $\begin{array}{c}\text { Grain } \\
\text { number }\end{array}$ & $\begin{array}{c}\text { Grain } \\
\text { weight }\end{array}$ & $\begin{array}{c}\text { Grain } \\
\text { diam. }\end{array}$ & MTG \\
\hline Mean & $\mathbf{3 8 . 8 9}$ & $\mathbf{7 . 5 0 2}$ & $\mathbf{1 0 . 9 6}$ & $\mathbf{4 . 9 2}$ & $\mathbf{5 . 6 3 4 1}$ & $\mathbf{2 0 . 3}$ & $\mathbf{4 . 6 4 8 3}$ & $\mathbf{6 . 7 5 5}$ & $\mathbf{2 2 8 . 2 1 3}$ \\
\hline Variance, s $^{\mathbf{2}}$ & 33.27 & 9.842 & 11.25 & 3.36 & 6.1393 & 66.4 & 4.1545 & 0.527 & 892.222 \\
\hline Std. error,s & 5.76 & 3.137 & 3.35 & 1.83 & 2.4777 & 8.1 & 2.0382 & 0.725 & 29.870 \\
\hline CV \% & $\mathbf{1 4 . 4 3}$ & $\mathbf{4 1 . 8 1 5}$ & $\mathbf{3 0 . 5 6}$ & $\mathbf{3 7 . 1 9}$ & $\mathbf{4 3 . 9 7 6 8}$ & $\mathbf{3 9 . 9}$ & $\mathbf{4 3 . 8 4 8 2}$ & $\mathbf{1 0 . 7 3 2}$ & $\mathbf{1 3 . 0 8 8}$ \\
\hline
\end{tabular}

\section{CONCLUSIONS}

The morphological characteristics of the pea, the Alvesta variety, had specific aspects. The choice of this variety was that it has recent genetic improvements, especially for its high productive potential.

Being a variety with a relatively small (low) size, the stem had lengths of $36-45 \mathrm{~cm}$. This may be a condition increasingly induced by maximizing production in a superior, intense crop system. The plants had a more dominant total mass between 5 and $12.5 \mathrm{~g}$. The stem formed a multitude of floral nodes, these being distributed at quite small intervals. They dominated the stems with 5-7.5 knots.

The number of pods formed ranged from 4-6 per plant, and their biomass was between 4 and $8 \mathrm{~g}$. The number of grains formed ranged from 13-25 per plant, and their weight was between 3 and $6 \mathrm{~g}$. The diameter of the grains was between 6.5 and $7.5 \mathrm{~mm}$. The absolute mass of the grains was at a maximum level of 200-230 g, and that means relatively large grains.

Simple correlations were established between all the studied characters, with some differentiations. Positive correlations were obtained between the studied morphological characters and were statistically assured. Only the diameter of the grain and the mass of a thousand grains were correlated with some insignificant characters.

The variability of the morphological characters studied in the Alvesta pea variety were generally high. The cause could be explained by the dry background in certain periods of vegetation.

\section{REFERENCES}

Bâlteanu, G., Bîrnaure V. (1989). Fitotehnie [Crop Production], Ed. Ceres, București: 319- 330.

Ellis, T.H.N., Poyser, S.J. (2002). An integrated and comparative view of pea genetic and cytogenetic maps. New Phytologist, 153 (1), 17-25.

Kreplak, J., Madoui, M.-A., Burstin, J. (2019). A reference genome for pea provides insight into legume genome evolution. Nature Genetics, 51 (9), 1411-1422.

Lawrence, J.M., Grant, D.R. (1963). Nitrogen Mobilization in Pea Seedlings. II. Free Amino Acids.. Plant Physiology. 38 (5), 561-566.

Myers, J.R. Baggett, J.R. Lamborn, C. (2010). Origin, History, and Genetic Improvement of the Snap Pea ( Pisum sativum L.), In J. Janick, ed. Plant Breeding Reviews, John Wiley \& Sons, Inc.:93-138,

Pownall, TL, Udenigwe, CC, Aluko, RE (2010). Amino acid composition and antioxidant properties of pea seed (Pisum sativum L.) enzymatic protein hydrolysate fractions. Journal of Agricultural and Food Chemistry. 58 (8,: $4712-$ 4718.

Sturzu, R.,, Ene, A.M.,, Melucă, C., Iordan, C. (2016). Evaluarea principalelor caracteristici morfoproductive ale genotipurilor de mazăre de câmp (Pisum sativum L.) din colecția de la S.C.D.A. Teleorman [Evaluation of the main morphoproductive characteristics of the genes of field peas (Pisum sativum L.) from the collection of S.C.D.A. Teleorman]. Analele INCDA Fundulea, 84, 95-106. 